Orbis Tertius, vol. XXIV, $\mathrm{n}^{\circ}$ 30, e123, noviembre 2019-abril 2020. ISSN 1851-7811

Universidad Nacional de La Plata

Facultad de Humanidades y Ciencias de la Educación

Centro de Estudios dđeoría y Crítica Literaria

\title{
Una lección de geografía: mapas y vistas a vuelo de pájaro en las crónicas de Roberto Arlt
}

\author{
A lesson in geography: maps and bird's-eye views in the chronicles of Roberto Arlt \\ Pilar María Cimadevilla \\ Universidad Nacional de la Patagonia San Juan Bosco - \\ CONICET, Argentina \\ pilar_cimadevilla@yahoo.com.ar
}

\section{Resumen:}

La propuesta de este artículo consiste en analizar cómo en las notas tituladas "Tiempos presentes" y "Al margen del cable", impresas entre 1937 y 1942 en El Mundo sin fotos o ilustraciones que las acompañen, Roberto Arlt se sirve de las imágenes de prensa impresas en otras secciones del matutino como disparadores para el armado de sus textos. Para ello se observará el modo en que el escritor se desempeña en esta zona de su obra periodística como un cronista cartógrafo al incorporar en sus artículos ciertas referencias geográficas y espaciales que se vinculan con la proliferación de mapas y de vistas urbanas que, día a día, se publicaban en la sección cablegráfica y en la tapa del matutino a propósito de los acontecimientos en torno a la Segunda Guerra.

Palabras Clave: Arlt, Prensa, Crónica, Imagen, Literatura argentina.

\section{Abstract:}

The proposal of this article is to analyze how in the notes entitled "Tiempos presentes" and "Al margen del cable", printed between 1937 and 1942 in El Mundo without photos or illustrations that accompany them, Roberto Arlt uses the press images printed in other sections of the newspaper as triggers for the assembly of their texts. To this end, we will observe the way in which the writer works in this area of his journalistic work as a cartographer chronicler, incorporating in his articles geographical and spatial references that are linked to the proliferation of maps and urban views that day by day they were published in the cable section and on the cover of the paper about the events surrounding the Second War.

KeYwords: Arlt, Press, Chronicle, Image, Argentine literature.

La segunda guerra mundial fue una lección de geografía universal. Eric Hobsbawm (2003, p. 32)

De regreso al país, Arlt no volverá a escribir sobre Buenos Aires. La ciudad que lo cautivó durante sus primeros años en El Mundo, ahora, entra en sus ojos como un reflejo opaco que le devuelve solo aquello que quiere ver: las convulsiones extranjeras. Porque Arlt ya no es el mismo. Los meses transcurridos en tierras foráneas no agotan su manifiesto deseo de viaje sino que, por el contrario, lo potencian y lo transforman en una suerte de obsesión por asir el mundo. El escritor regresa al país en mayo de 1936, pero sus ojos continúan perdidos entre los mares y las ciudades que aún no conoce. ${ }^{1}$

Por eso, el trabajo escriturario que realiza en la configuración de su nueva columna, impresa sin ningún tipo de imagen en la página seis de El Mundo y titulada en un principio “Tiempos presentes” y más tarde "Al margen del cable", ${ }^{2}$ genera un efecto sorpresa en sus lectores. ${ }^{3}$ En algunos casos de enojo o decepción frente a los cambios (estas notas no conservan la lengua de la calle de la primera etapa y se separan también de las atmósferas agobiantes de las novelas), en muchos otros de fascinación, porque ahora el cronista sabe que media página le alcanza para experimentar con el lenguaje, los géneros literarios, las imágenes propias, y también las ajenas, de un mundo desquiciado entre dos guerras.

Como bien señalan los pocos pero contundentes estudios críticos sobre este corpus, la característica más notable de estos textos reside en la inclusión de cables telegráficos tomados de otras secciones del mismo 
periódico, y también de otros medios, como punto de partida para el desarrollo de la crónica. En relación con esto Saítta observa que es "en la mezcla caótica y desordenada de los cables de noticias" donde Arlt "encuentra los temas a partir de los cuales construir su narración” (Saítta, 2008, p. 252). ${ }^{4}$ Pero además, agrega Juárez, estos textos no sólo resultan excéntricos en el corpus total de las crónicas para El Mundo, sino que, además, inauguran un nuevo género en la literatura de Arlt. Esto sucede, según la autora, cuando el cronista "rescata lo perdido en las páginas de los diarios mediante el despliegue y, en muchos casos, la literaturización de la noticia que, en relación a los grandes acontecimientos que refieren los periódicos, puede entenderse como marginal o accesoria" (2010, p. 212). ${ }^{5}$ Es que de algún modo, en estos artículos, es el mismo cronista quien parecería "inventar" las novedades internacionales, "[n]o porque haga ficción o tergiverse los hechos, sino porque es capaz de descubrir, en la multitud opaca de los acontecimientos, los puntos de luz que iluminan la realidad. En nadie es tan clara como en Arlt la tensión entre información y experiencia” (Piglia, 2009, p. 11).

Sin embargo, junto con el trabajo de expansión de los cables internacionales puede señalarse que otro de los rasgos que distinguen a estas notas entre todo el material cronístico arltiano es la implantación de un nuevo tipo de visualidad que, paradójicamente y a diferencia de lo que ocurre con las aguafuertes porteñas ilustradas por Luis Bello y las notas de viaje acompañadas por las fotos del mismo Arlt, no incluye imágenes materiales. Porque, como veremos a lo largo de este artículo, en esta zona de su obra periodística, el escritor se sirve del lenguaje para ilustrar el mundo. Inspirado en las imágenes de prensa que día a día veía en el mismo periódico y en otros medios, y también en el acervo de fotografías, pinturas, grabados y descripciones espaciales vistas y leídas a lo largo de su vida, el cronista reconstruye a través de la palabra estampas que recuerda haber visto para certificar su versión de los hechos, proponiendo, así, recorridos visuales creativos y sugerentes. Si como refiere Piglia, el afán del aguafuertista en todo su trabajo periodístico reside en "fijar una imagen, registrar un modo de ver" (2009, p. 12), en estas notas el proyecto se volverá aún más ambicioso: Arlt intentará mostrar a los lectores porteños aquello que sus ojos tampoco pudieron contemplar.

De acuerdo con esto, nos proponemos analizar cómo la impronta visual de estas notas impresas sin fotos o dibujos también se vincula con la propagación de representaciones sobre la guerra efectuada en las páginas de El Mundo. Tal como se observará aquí, al igual que sucede con los cables de noticias, las imágenes de prensa también se convirtieron en fuentes y en disparadores para el armado de las crónicas arltianas. En efecto, por un lado, veremos el modo en que el escritor se desempeña en estos artículos como un cronista cartógrafo en tanto "descriptor de mundos" (Alpers). Porque, en sintonía con la relevancia que adquieren los mapas dentro del periódico, muchos de estos artículos periodísticos comienzan haciendo en primer lugar una referencia explícita a los límites geográficos de los espacios en los que se desarrollan los argumentos periodísticos. Arlt mira/imagina desde arriba las ciudades internacionales protagonistas y señala detalles cartográficos antes de comenzar sus relatos de prensa. Pero, además, en un segundo momento y en paralelo con el lugar que ocupaban los mapas en el armado de las nuevas imágenes del mundo, nos detendremos en la representación de las vistas urbanas a partir de las que Arlt suele comenzar sus notas para analizar el vínculo entre esa recurrencia y la yuxtaposición de imágenes fotográficas que día a día se imprimían en la tapa del periódico. Como veremos, junto con las fotos de las trincheras o con los retratos de los personajes protagonistas de las noticias del día, se publicaban en la primera plana vistas a vuelo de pájaro que mostraban a los lectores porteños los escenarios internacionales en los que transcurrían los acontecimientos destacados. Estudiaremos, entonces, el modo en que Arlt comenta y expande no sólo los cables internacionales, sino también la información concisa y visual de los mapas y las imágenes de prensa. ${ }^{6}$

\section{MAPAS}

Estaba sentado en el porche leyendo un libro sobre la guerra. Era un libro de historia, y leía acerca de todos los combates en que había participado. Era lo más interesante que había leído nunca. Se dijo que ojalá hubiera más mapas. Con un sentimiento positivo anhelaba leer todas las buenas historias 
cuando salieran con buenos y detallados mapas. Ahora sí que estaba aprendiendo de verdad sobre la guerra.

Ernest Hemingway (2016, p. 181)

"La guerra ha dejado de ser una aventura para transformarse en escuela de mecánica aplicada. ¿Qué es, si no, un conductor de tanques, un artillero de cañones antiaéreos, un idóneo en comunicaciones de campaña? Técnicos, técnicos y técnicos. La única aventura, todavía, se refugia en la geografía” (Arlt, 1940a). En sintonía con las grandes preguntas de la época en torno al destino del hombre en un mundo mediatizado por los avances tecnológicos, para finales de la década del treinta, Arlt encuentra que la guerra ha devenido en un espectáculo opaco e inentendible. Ya no hay héroes porque los protagonistas reales, los soldados y sus superiores, son anónimos. Tampoco hay enfrentamientos cuerpo a cuerpo, ni compasión, ni narraciones, porque la épica también ha sido absorbida por los cables telegráficos. ${ }^{7}$ Sin embargo, existe para Arlt una arista en la cual la representación de la conflagración mundial coincide con los argumentos motivantes de relatos como los de Emilio Salgari (a los que hace referencia en más de una ocasión): el deseo por conocer los ríos, los pueblos, las tormentas y los desiertos más recónditos del planeta. La aventura, tal como figura en la cita, no está en las noticias diplomáticas ni en los frentes de batalla, sino en la oportunidad de sentir por primera vez que es posible asir el mundo. Así, encontramos que los mapas que día a día se publicaban en el periódico durante el desarrollo de la guerra española se fueron multiplicando y ampliando con el correr de los meses. Si se comparan las Figuras 1 y 2 puede notarse una diferencia sustancial en el protagonismo que adquirieron dentro de la sección cablegráfica. ${ }^{8}$ Además, ya iniciada la Segunda Guerra, encontramos también la publicación de notas escritas mayormente por técnicos y militares que incluían mapas en el espacio de la crónica. Roberto Calegari (capitán de fragata), Dixit (seudónimo que desconocemos a qué periodista perteneció) y el Coronel J. articularon en el cuerpo de sus crónicas información escrituraria e información visual gracias al agregado de mapas.

FIGURA 1

El Mundo, 23 de marzo de 1939

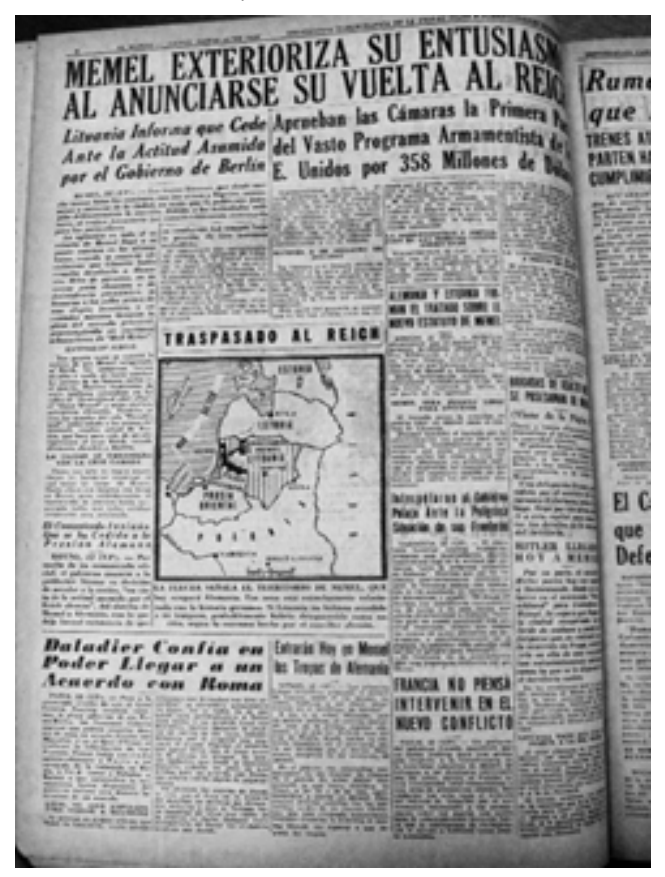


FIGURA 2

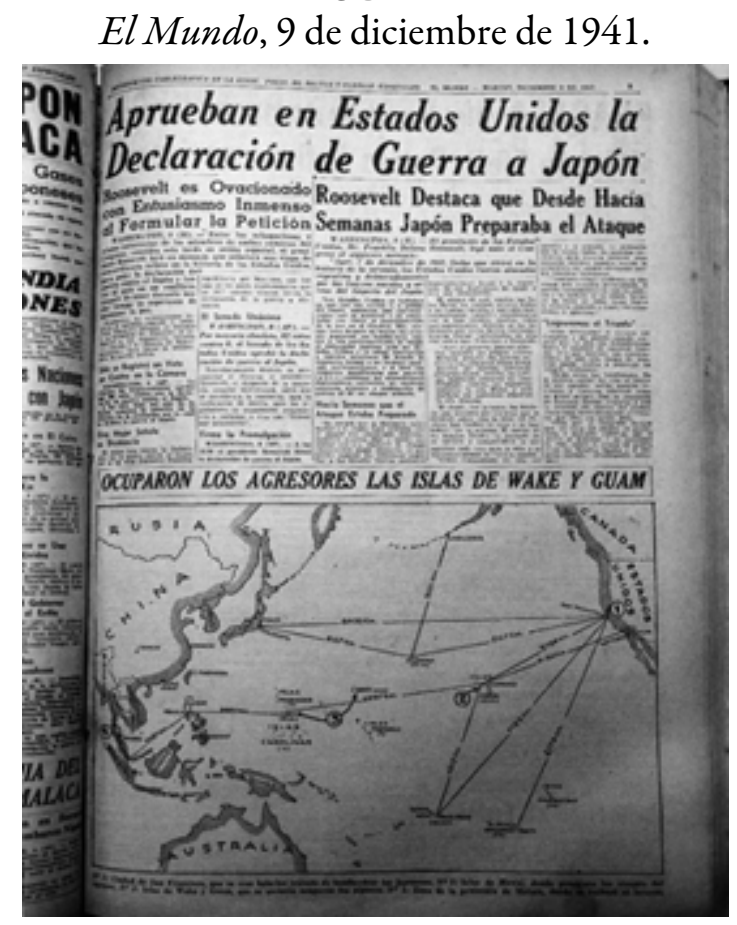

Un ejemplo claro es el que figura en "Objetivo estratégico y no económico persigue la invasión a Noruega", publicada el 16 de abril de 1940, porque allí Calegari utiliza en su texto un mapa anotado para analizar las consecuencias del ataque alemán en tierras noruegas. Al comienzo de su crónica, el capitán de fragata señala la noticia concreta: "La guerra llevada a Noruega, por la invasión alemana, continúa con toda su intensidad, y en base a las informaciones que nos llegan podemos efectuar una apreciación suficientemente acertada sobe el estado en que se encuentran las operaciones emprendidas" (1940a); luego, apoyándose en las indicaciones que figuran en el mapa impreso junto al texto -ubicación de las bases nazis, frentes bloqueados, cantidad de kilómetros que separan Inglaterra de los frentes alemanes, etc. (Figura 3)-, intenta explicar, siempre teniendo en cuenta la posición geográfica de los tres países en cuestión, el porqué de dicha invasión y sus posibles consecuencias:

Es interesante investigar cuál ha sido el móvil que ha impulsado a Alemania a realizar una empresa de tanta magnitud, en cuya preparación no puede haber sido descartada la posibilidad de sufrir gruesas pérdidas, y lo que es más importante aún, de correr un riesgo de tal consideración, que pudiera significarle un fracaso. Surge de inmediato, en consecuencia, que el objetivo de esa operación riesgosa y en vasta escala, debe ser de fundamental importancia, y acaso la mala situación estratégica de Alemania respecto a su principal enemigo, Gran Bretaña, como consecuencia de su situación geográfica (1940a).

Como puede verse en este caso y día a día en las páginas de la sección cablegráfica de El Mundo, los mapas resultaban una herramienta fundamental para ubicar a los lectores en los escenarios de batalla, mostrar estrategias, y señalar distancias espaciales difíciles de descifrar. Ciertamente como señala el mismo Calegari en otra de sus notas: "La posición geográfica que un país ocupa en el mundo, es un factor fundamental en la estrategia naval, es decir, en la conducción de la guerra. Como consecuencia, el plan de operaciones que se debe adoptar durante el conflicto responde, en especial, a las exigencias que impone la geografía dado que ésta no admite modificaciones" (1940b). En efecto, los escritores y periodistas sabían que para pensar la guerra desde Argentina era necesario brindar las coordenadas geográficas donde se desarrollaban los enfrentamientos europeos. Pero también sabían -en sintonía con la cita de Arlt recuperada más arriba-, que no era posible ubicar a los lectores únicamente a través de las representaciones textuales que figuraban en las diferentes noticias y crónicas. Por eso, frente al tedio de las informaciones sobre artillería, diplomacia y movimientos 
estratégicos, los mapas se convirtieron en este contexto en un artilugio eficaz y entretenido para que estos cronistas-técnicos pudiesen ofrecer información precisa y clara a los lectores porteños (Figura 4).

FIGURA 3

Roberto Calegari, El Mundo, 16 de abril de 1940

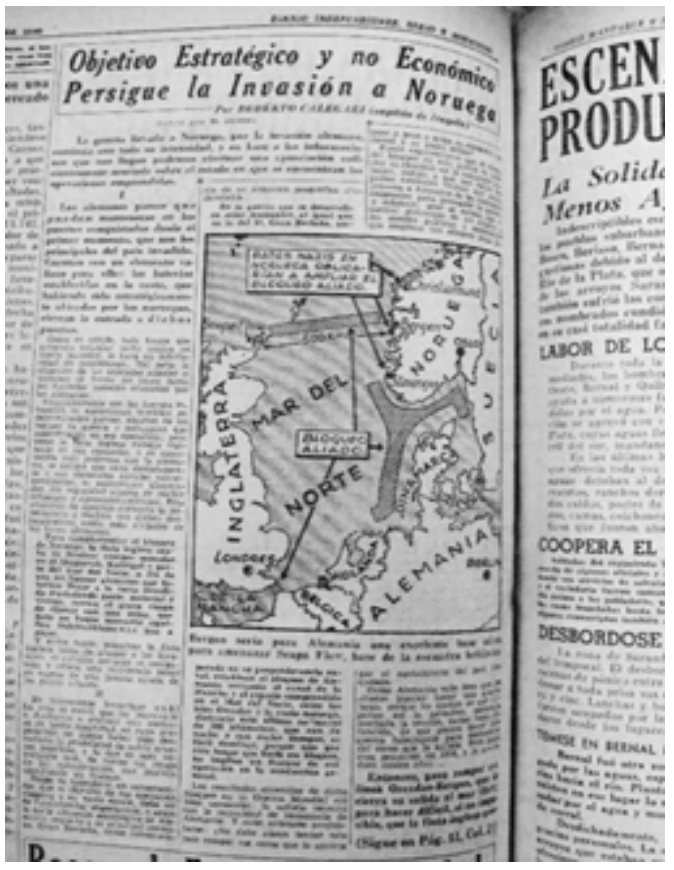

FIGURA 4

Dixit, “Situación económica de Alemania. La guerra por dentro”, El Mundo, 24 de junio de 1940

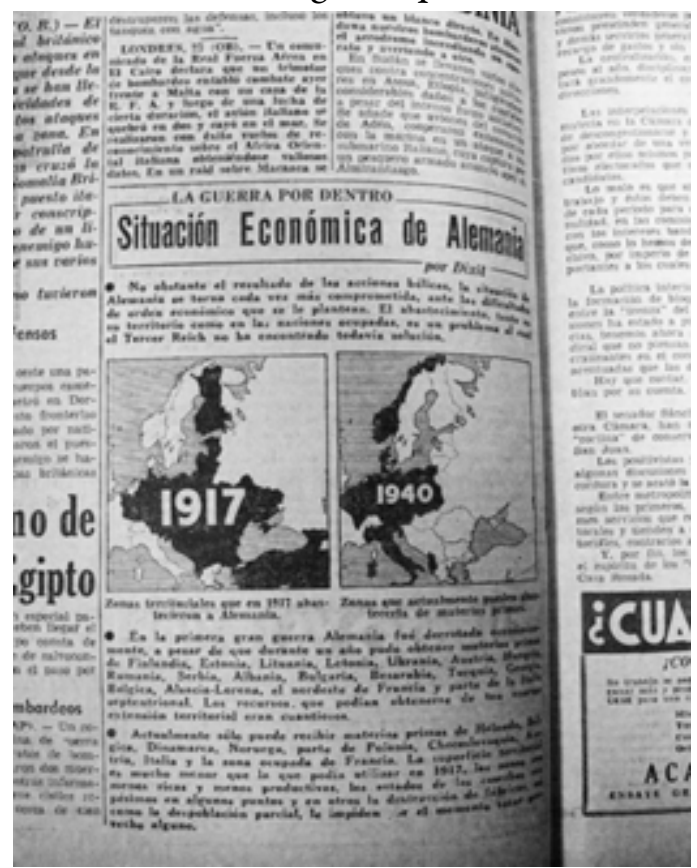

En el caso de Arlt, si bien sus textos no se vinculan escriturariamente con las notas de Calegari o con las del Coronel J. ni tampoco fueron impresos junto con imágenes (fotografías, ilustraciones o mapas), se registra en muchos casos una suerte de "impulso cartográfico" en el nivel de la representación. En su estudio sobre el arte holandés del siglo XVII, Svletana Alpers señala que "seguramente no hubo nunca otra época ni lugar en 
que se produjera mayor coincidencia entre cartografía y arte figurativo" (2016, p. 215). El análisis sobre este hallazgo llevado adelante por la historiadora del arte nos sirve, salvando la distancia epocal y genérica, como un disparador para pensar el modo en que los mapas y el trabajo cartográfico es retomado y propulsado por la prensa en el contexto de las guerras mundiales. En este sentido, creemos que, frente a la mutación de las fronteras geográficas y a la proliferación de mapas, Arlt intentó (lejos, pero en cierta sintonía con los cuadros de Vermeer y en conexión con otros cronistas, autores y periodistas $)^{9}$ lograr en el espacio de la crónica "una recomposición del mundo" (Alpers, 2016, p. 221).

La guerra promovió, así, la aparición de enviados especiales, de fotografías violentas y también de mapas. Y esto produjo efectos en las representaciones escriturarias que, al menos en Arlt, repercutió no sólo en sus notas dedicadas a los avatares bélicos, sino en el conjunto total. Porque las descripciones del escritor, tal como puede verse cuando se recorren todas las crónicas que publica hasta 1942, no se acotaron a las noticias sobre las batallas, sino que también mostraron las lenguas, las costumbres, los personajes, la historia y un sinnúmero de acontecimientos excéntricos sucedidos en las ciudades internacionales que día a día estaban en boca del mundo entero (Berlín, Praga, París, Madrid, Londres, Nueva York, entre muchas otras). La aparición de este "impulso cartográfico" desatado por una crisis que mueve y crea nuevas fronteras inaugura un nuevo recurso dentro de la obra periodística del escritor que sintoniza con las operaciones del diario y las imágenes concretas que allí se publicaban:

Si usted toma un mapa de las regiones árticas y apoya su dedo en 'Grant Land' (una manchita olivácea tatuada de referencias
en rojo), su dedo se encuentra a los 83 grados de latitud norte. Moteadas con azul de acuarela y verde esmeralda, se extienden
las tierras del confín postrero. Si usted continúa subiendo su dedo apoyado en el mapa, 1 grado más al norte, 84 grados, ya no
encuentra tierras moteadas con los deliciosos colores de la geografía. Un grado más hacia el norte, tropieza con el círculo 85.
Un cono blancuzco mancha el verde acuático del Polo Norte. Y el cono blancuzco muestra su leyenda, eternamente redactada
en el idioma de todos los mares: Unexplored. Inexplorado. Estamos en el círculo de blancura eterna. Líneas de puntos rojos
apuñalan con sus triangulaciones el último círculo, el círculo 85 . Y algunos nombres, también en tinta roja: 'Dicovered by
Peary. April 6,1909 '. La fecha es heroica, señores. [...] Nombres en tinta roja sobre un océano deliciosamente verdoso como
una tarde de verano, cuando las muchachas sienten que les pesa la blusa sobre el pecho. Y allí las montañas están orientadas
por la tormenta con bloques de hielo. Es un paisaje hostil, como lo fue la víbora para el hombre en los primeros días de la
creación. Arriba un cielo negro, pintado con alquitrán, abajo, colmilluda, la pared vertical del hielo. Chorreando tubos de
nieve al pie de un lago en el que se derrite lentamente una chalupa de nieve (Arlt, 1938b).

La nota, cuyo tema reside en el aniversario del naufragio de un rompehielos frente a las Islas Siberianas, comienza de un modo fragmentario a partir de la yuxtaposición de oraciones breves que funcionan al modo de instrucciones para que el lector se ubique en el planisferio. A medida que el texto avanza, el cronista agrega a dichas descripciones metáforas y comparaciones que poetizan la nota y dan paso a la literatura: el océano es verde "como una tarde de verano, cuando las muchachas sienten que les pesa la blusa sobre el pecho"; el paisaje es hostil "como lo fue la víbora para el hombre en los primeros días de la creación". A diferencia de lo que pudo verse anteriormente en la nota de Calegari, aquí el mapa imaginario que Arlt representa en su crónica pierde el estatuto de documento y se transforma en un lienzo ficcional que muestra la fascinación del escritor. Es que, al mismo tiempo que el cronista necesita de la referencia geográfica, debe impedir que la corroboración del dato quiebre el límite siempre endeble que separa la información de la narración en el formato crónica (Ramos, 1989, p. 110-111). Otro ejemplo es el que figura en "Puede que si...puede que no...":

En Costa Rica, sobre el Golfo de México, aproximándose al canal de Panamá, la costa dibuja sobre el agua el relieve de un arco que parece la cola de un gato. Se llama Punta Arenas. Hasta hace algunos años, el paraje carecía en absoluto de importancia. [...] Un día llegaron unos japoneses [...] sembraron algodón y luego se quedaron concienzudamente tranquilos bajos sus anchos sombreros de esterillas. [...] Mi segunda historia comienza en Colombia, 400 millas de vuelo al sur del canal de Panamá, en lo más intrincado del Valle de Cauca. Para llegar hasta las localidades de Santa Ana hay que cabalgar durante diez horas. En algunos trozos el camino tiene que ser andado, tan arisco es el terreno. Hace nueve años (¡ayer!) diversos súbditos japoneses experimentaron un interés muy vivo por la agricultura y adquirieron, aproximadamente, quinientos acres de tierra (Arlt, 1940c). 
Los estadounidenses, comenta Arlt más adelante, sospechan que todas esas plantaciones que los japoneses llevaron a cabo en diferentes puntos del planeta se hayan convertido en bases militares. Una vez más, antes de sumergirse en la noticia, el cronista ubica a los lectores en el mapamundi a partir de indicaciones espaciales precisas. No obstante, aquí aparecen junto a la descripción de los accidentes geográficos -el dibujo que, desde lo alto, presenta el contorno de Costa Rica-, instrucciones que ya no indican cómo ubicarse, sino cómo recorrer el espacio señalado: "Para llegar hasta las localidades de Santa Ana hay que cabalgar durante diez horas. En algunos trozos el camino tiene que ser andado, tan arisco es el terreno". En este sentido, y en correlación con las teorizaciones de Michael de Certeau puede señalarse que, por momentos, las referencias espaciales trazadas por Arlt en sus artículos mantienen algún tipo de vinculación con las instrucciones de los mapas medievales:

En particular, si se toma el "mapa" bajo su forma geográfica actual, aparece que en el curso del periodo marcado por el nacimiento del discurso científico moderno (del siglo XV al XVIII), lentamente se libró de los itinerarios que eran su condición de posibilidad. Los primeros mapas medievales llevaban solamente los trazos rectilíneos de los recorridos (indicaciones performativas que, por otra parte, se refieren más que nada a unos peregrinajes), con la mención de etapas que debían seguirse (ciudades donde pasar, detenerse, alojarse, rezar, etcétera) y de distancias acotadas en horas o en días, es decir en tiempos de camino. Cada mapa era un memorándum que prescribía acciones. Domina el recorrido que deberá hacerse (2000, p. 132).

Entonces, si en un sentido amplio, la cartografía puede ser definida como "la tendencia a documentar o describir la Tierra en imágenes" compartida, para Alpers, "por topógrafos, artistas, impresores y público en general en los Países Bajos durante el siglo XVII” (2016, p. 251), y para nosotros, también por los periodistas, editores y lectores que seguían de cerca los avatares bélicos de la primera mitad del siglo XX, no resulta extraño que ese "impulso cartográfico" generalizado haya atravesado y modificado en parte la escritura de las notas arltianas. Pero, además, estas crónicas cartográficas en las que el escritor periodista describió el mundo con sus golfos, bahías, océanos y picos de montaña no sólo se vinculan con la materialidad de los mapas que se imprimían en el periódico, sino que también mantienen conexiones con las fotografías aéreas que casi a diario se publicaban en la tapa del mismo matutino.

\section{Vistas a VUELo de PÁJARo}

Ciertamente, cuando se revisan los ejemplares de El Mundo de finales de los años treinta y principios de los cuarenta, se advierte en el trabajo de los diagramadores la puesta en acción de una suerte de fórmula muy efectiva en el diseño de la tapa: debajo de los grandes titulares sobre las noticias del día, y marginadas hacia el costado derecho, aparecen entre tres y cuatro fotografías que, yuxtapuestas, resumen las novedades desarrolladas dentro del periódico: el lugar en el que sucedieron los acontecimientos, quiénes fueron los participantes y, en muchos casos, se agrega algún detalle sobre el horror de las contiendas. Así, como puede verse en las Figuras 5 y 6 , aparecen en primer plano fotografías de las ciudades internacionales protagonistas tomadas desde lo alto y más abajo retratos de personajes involucrados (embajadores, políticos, diplomáticos, generales) junto con capturas en las que figuran aquellos sujetos anónimos que participan activamente de la guerra (aviadores, soldados, militares, civiles) y, también, con las imágenes que muestran las consecuencias de las batallas (por ejemplo, fotos de ciudades destruidas). 
FIGURA 5

El Mundo, 2 de junio de 1937

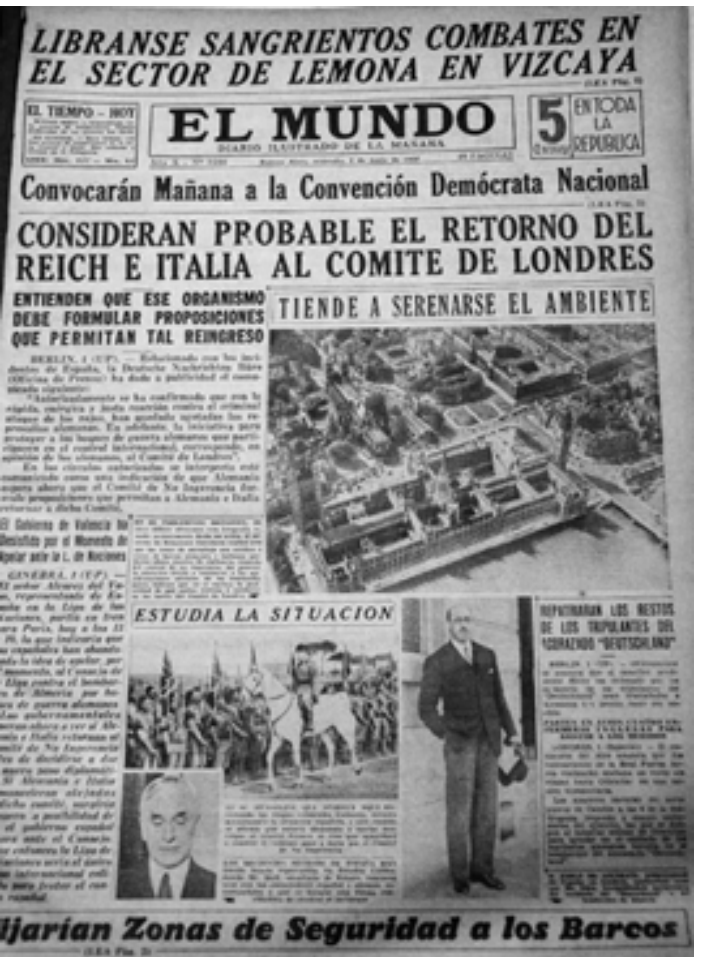

FIGURA 6

El Mundo, 14 de octubre de 1937

Acuerdan un Plazo de Quince Dias Para Discutir el Asunto de los Voluntarios

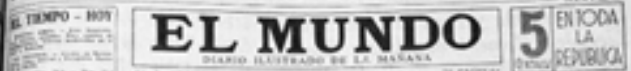
ESSUVERA HOY E RADIGALISMOSIASSTE ALA ASAMBLEALEGSLATINA PROPONESE UNA DEMOSTRACION NAVAL. FRANCOBRITANICA EN EL HEDITERRANEO

nis Eucara Ea y Otrus Metitu Bombardean Nuevamente a Port - Bou en Prenision de cue lialia in on

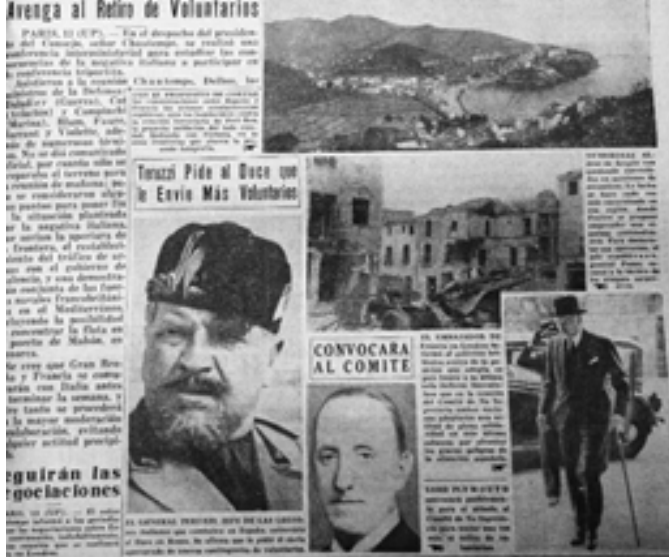

Iadrid Soporta Otro Violento Bombardeo 
En relación con esto, puede verse que, como las tapas de ElMundo, muchas de las notas internacionales de Arlt (algunas sobre la guerra y otras tantas no) empiezan a partir de la representación de imágenes urbanas a vuelo de pájaro:

\begin{abstract}
Cuando uno contempla en una fotografía aérea de la orilla de oro de la isla de Manhattan la curvada verticalidad de los rascacielos, elevados sobre el parque que extiende su trapecio de terciopelo verde a lo largo de las aguas del Atlántico, o sigue, junto a la terraza de los rascacielos, el deslizamiento de un dirigible, pequeño como el huso de una hilandera, entre las escalonadas torres de Babel de la terrible urbe; cuando uno contempla de noche los iluminados planos de estos millones y millones de ventanas que sumergen sus lápices de fuego blanco y rojo en las tinieblas de la noche, como si pretendieran escribir en el cielo con letras de luz el poema de la soberbia potestad del hombre, se duda en aceptar si se contempla un espectáculo terrestre, y se piensa que se ha llegado a la titánica capital del imperio del hierro. Hace un tiempo, en Estados Unidos, que los rascacielos expresaron la última etapa de la prosperidad de un hombre que había culminado en la industria, en el comercio o en las finanzas. Las montañas de acero, cemento y cristal que llevan el nombre de edificios Carnegie, Morgan, Edison o Rockefeller estuvieron destinadas a expresar la voluntad de potencia del triunfador. Su éxito inflamó luego el entusiasmo de los especuladores. [...] y por este diabólico camino cada rascacielos se convirtió en una ciudad vertical, como si de pronto el planeta Tierra se hubiera tornado infinitamente más pequeño que la Luna y no hubiera espacio dónde moverse sin peligro de rodar al abismo (1940d).
\end{abstract}

Para presentar el tema de la nota -la sobreabundancia de rascacielos en Estados Unidos- Arlt imprime desde el cielo una imagen sobre esta ciudad internacional en la que nunca estuvo y a la que, probablemente, sus lectores tampoco conozcan. ${ }^{10} \mathrm{Y}$ es que las vistas a vuelo de pájaro, tal como señala Barthes cuando analiza cómo se ve París desde la punta de la Torre Eiffel, invitan "inevitablemente a imaginar una historia" (2002, p. 63-64). Se pregunta el teórico francés: “¿Qué es, en efecto, un panorama? Es una imagen que tratamos de descifrar, en la que intentamos reconocer lugares conocidos, identificar señales" (2002, p. 63). Como los mapas, las fotografías tomadas desde lo alto, generan la ilusión de totalidad. Cuando se mira una vista aérea se cree poder abarcar de una vez todo el espacio, porque mirar una ciudad a vuelo de pájaro es incorporarla a la naturaleza, es ver su conexión con el mar, con el río, con la montaña, con el desierto. Sin embargo, esa pequeña escala, lejos de mostrárnoslo todo, convierte un bosque con pinos, sus casas, sus arroyos, en una mancha verde. Como puede verse en la cita de Arlt, las formas y los contornos que se ven desde el cielo, lejos de mostrar en detalle el universo representado, resultan un punto de partida para el desarrollo de la crónica. Encontramos así que, del mismo modo en que el escritor recurre en estas notas al formato del cable telegráfico, retoma también en su escritura las imágenes aéreas que día a día inauguraban el material informativo del periódico para referir tanto a noticias vinculadas con la guerra, así como también a novedades internacionales desvinculadas de los escenarios bélicos.

Otro ejemplo claro es el que se observa en el inicio de “¿Está loco o se hace el loco Al Capone?”. Dice el escritor: "La Isla de Alcatraz vista desde un avión tiene la forma de un superdreadnought. En este superdreadnought de roca viva se abren limpios corredores embutidos en los muros, corren caños de agua caliente y fría. Alcatraz no es un hotel, sino un presidio. En torno murmuran las aguas del Pacífico. En este presidio, ventrudo, belfudo, catadura de gorila humano, se aloja Al Capone, el conspicuo. Al Capone, el patrón del crimen de la América del Norte" (Arlt, 1938a). Si en la tapa del diario del 27 de agosto de 1940, los diagramadores del periódico colocaron en primer lugar una foto aérea de la capital alemana, y debajo ubicaron la imagen-noticia que muestra a los aviadores y a los políticos involucrados en los bombardeos entre Berlín y Londres; en esta cita de Arlt, encontramos que, si bien esta noticia no tiene vinculación con la guerra, para presentar al personaje en cuestión (Al Capone) el cronista representa primero una vista de la ciudad escenario desde lo alto. Así, puede constatarse que el procedimiento que figura en estas notas no solo retoma movimientos y recursos de las diferentes crónicas y secciones textuales del periódico, sino que también presenta articulaciones con el tipo de fotografías que se incluían dentro del mismo diario.

Mapas y vistas urbanas resultan, por lo tanto, herramientas decisivas para el armado de las notas "Al margen del cable" que, como se vio en el análisis, deben ser pensadas en conjunto, ya que, como señala Alpers, los dos tipos de imágenes que presentan "por origen y naturaleza, una esencial similitud con los mapas [son] el paisaje 
panorámico o cartográfico [...] y la vista urbana o topográfica” (2016, p. 241). El "impulso cartográfico" que aparece, entonces, en estas crónicas que Arlt dedica a los más diversos acontecimientos en torno a la guerra y a los cambios que la crisis europea produjo en el mundo, responde tanto a una necesidad por ubicar las contiendas en tiempo y espacio, como también al cambio de velocidad en la circulación de la información, a la posibilidad de ver en el mismo momento y desde lejos lo ocurrido a través de imágenes fotográficas y también a la incorporación de nuevos puntos de vista a través de los cuales mirar el espacio -las fotografías aéreas- que, de algún modo, se acoplaron a los modos tradicionales de ver el mundo -los mapas-. Por último, resta señalar que la lección de geografía que Arlt arma en sus crónicas para los lectores del periódico no les permite armar un mapa claro y real sobre la guerra, sino que los instiga a viajar por el planisferio de un modo desordenado y arbitrario para correrse del lugar de porteños y soñar con conquistar desde el cielo un mundo que, aunque atravesado por el horror, resulta cada vez más cercano.

\section{FuenTES}

Arlt, Roberto (1938a). “¿Está loco o se hace el loco Al Capone?”, El Mundo, 12 de enero.

Arlt, Roberto (1938b). "En el círculo de la blancura eterna”, El Mundo, 1 de noviembre.

Arlt, Roberto (1940a). "No por amor visitará Macdonald a Modjadji”, El Mundo, 5 de enero.

Arlt, Roberto (1940b). "Cuando Creso se desploma”, El Mundo, 8 de febrero.

Arlt, Roberto (1940c). “Puede que sí... puede que no...”, El Mundo, 6 de marzo.

Arlt, Roberto (1940d). "El rascacielos desalquilado”. Sin título, El Mundo, 8 de agosto.

Calegari, R. (1940a). “Objetivo estratégico y no económico persigue la invasión a Noruega”, El Mundo, 16 de abril.

Calegari, Roberto (1940b). “El problema estratégico en el mar Mediterráneo”, El Mundo, 24 de abril.

\section{Bibliografía}

Alpers, S. (2016). El arte de describir: el arte holandés en el siglo XVII. Buenos Aires, Argentina: Ampersand.

Barthes, R. (2002). La Torre Eiffel. En La torre Eiffel: textos sobre la imagen (pp. 63-64). Buenos Aires, Argentina: Paidós.

Benjamin, W. (1989). Experiencia y pobreza. En Discursos ininterrumpidos I. Filosofía del arte y de la historia (pp. 165-173). Buenos Aires, Argentina: Taurus.

Cimadevilla, P. (2016). Roberto Arlt fotógrafo. Sobre las aguafuertes fluviales, patagónicas y españolas. Anclajes, 20 (3), pp. 1-20. doi: http://dx.doi.org/10.19137/anclajes-2016-2031

Corral, R. (2009). 'Un argentino piensa en Europa': Roberto Arlt en sus últimas crónicas. En Roberto Arlt, Elpaisajeen las nubes: crónicas en El Mundo 1937-1942 (pp. 19-20). Buenos Aires, Argentina: Fondo de Cultura Económica.

De Certeau, M. (2000). La invención de lo cotidiano I. Artes de hacer. México: Universidad Iberoamericana.

Gnutzmann, R. (2004). Las aguafuertes. En Roberto Arlt: innovación y compromiso (pp. 135-190). Murcia, España: Asociación Española de Estudios Literarios Hispanoamericanos.

Gutman, M. (2011). Buenos Aires. El poder de la anticipación: imágenes itinerantes del futuro metropolitano en el primer Centenario. Buenos Aires, Argentina: Infinito.

Hemingway, E. (2016). La patria del soldado. En Cuentos (pp. 181-190). Buenos Aires, Argentina: Debolsillo.

Hobsbawm, E. (2003). Historia del siglo XX. Buenos Aires, Argentina: Crítica.

Juárez, L. (2010). Roberto Arlt en los años treinta. Buenos Aires, Argentina: Simurg.

Juárez, L. (2017). ¿Cómo narrar la guerra? Periodismo masivo y escritura literaria en Argentina. En Escritores y escritura en la prensa, La Plata, Universidad Nacional de La Plata, (en prensa). 
Piglia, R. (2009). Prólogo”. En Arlt, Roberto, El paisaje en las nubes: crónicas en El Mundo 1937-1942 (pp. 9-12). Buenos Aires, Argentina: Fondo de Cultura Económica de Argentina.

Ramos, J. (1989). Desencuentros de la modernidad en América Latina. México: FCE.

Saítta, S. (2008). El escritor en el bosque de ladrillos. Buenos Aires, Argentina: Debolsillo.

Saítta, S. (2017). Aguafuertes españolas con interludio africano. En Roberto Arlt. Aguafuertes de viaje: España y África (pp. 19-27). Buenos Aires, Argentina: Hernández Editores.

\section{Notas}

1 Como se sabe, Arlt viajó a España y a África como corresponsal de El Mundo entre febrero de 1935 y mayo desde 1936 desde donde envió, a diario y por avión, sus "aguafuertes de viaje". Sobre este viaje pueden consultarse: "Aguafuertes españolas con interludio africano" (Saítta 2017), Roberto Arlt en los años treinta (Juárez, 2010); "Roberto Arlt fotógrafo. Sobre las aguafuertes fluviales, patagónicas y españolas" (Cimadevilla, 2016), entre otros.

2 Cuando regresa a Buenos Aires se resiste a continuar con las aguafuertes porteñas y prueba en otras secciones. Como señala Saítta al respecto, el escritor "habla con Muzio Sánez Peña para que le permita escribir en la página cinematográfica dirigida por Calki (Raimundo Calcagno) [...]. Y es así como Arlt obtiene su encaprichado lugar en la página de cine. Los motivos no son obvios, pero Arlt se encarga de tornarlos explícitos: 'El cine es el único lugar donde encontrar algo digno de interés pues con la Guerra Civil española, el avance de Hitler o el peligro de una nueva guerra mundial lo realmente importante sucede en otro lado y Buenos Aires se convierte en una ciudad tranquila y aburrida...” (2008, p. 231).

3 Interesa destacar que, si bien las notas de Arlt no se imprimían a diario (su participación en esta etapa fue más bien intermitente), la página seis (adyacente a la sección cablegráfica) estaba destinada a la publicación de crónicas de diferentes escritores e intelectuales, entre ellos Enrique González Tuñón y Nicolás Olivari. En efecto, tal como observa Laura Juárez (2017), un rasgo distintivo de El Mundo que no parece repetirse en otros diarios consiste, precisamente, en la participación dinámica y activa de algunos escritores argentinos que reflexionan sobre los años circundantes al advenimiento de la Segunda Guerra.

4 En relación con esto, Gnutzmann observa que, en estas notas, Arlt "se ocupa de los temas más diversos, políticos, de sucesos, acontecimientos curiosos, muertes, suicidios, dando a todas un tono común de 'ficción'. En general, comienza con una creación de ambiente y suspenso; inventa diálogos; cita numerosos autores y obras que tratan un tema o una situación parecidos y emplea una rica adjetivación, imaginería, puntos suspensivos, exclamaciones, preguntas, etc. Por todo ello, es difícil establecer en estas notas el límite entre la noticia periodística y el texto literario” (2004, p. 137).

5 Este aspecto también es analizado por Rose Corral en '“Un argentino piensa en Europa': Roberto Arlt en sus últimas crónicas" (2009, p. 19-20).

6 Interesa destacar que estos no son los únicos modos en los que Arlt incluye la imagen en este corpus de notas. Nos restringiremos aquí al análisis de la influencia de los mapas y de las vistas a vuelo de pájaro únicamente por una cuestión de espacio.

7 Como señala Walter Benjamin en uno de sus artículos más afamados de 1933, "Experiencia y pobreza", una de las consecuencias de la Primera Guerra Mundial fue la pérdida de narradores: "¿Quién encuentra hoy gentes capaces de narrar como es debido? :Acaso dicen hoy los moribundos palabras perdurables que se transmiten como un anillo de generación en generación? [...] Entonces se pudo constatar que las gentes volvían mudas del campo de batalla. No enriquecidas, sino más pobres en cuanto a experiencia comunicable" (1989, p. 167-168).

8 Uno de los pilares fundamentales en la diagramación de El Mundo durante el desarrollo de la guerra en Europa fueron las incontables imágenes que apelaban a configurar un imaginario bélico sólido dentro del periódico. Vistas de ciudades, retratos de personalidades influyentes, mapas, cuadros y también fotografías de los frentes de batalla, armaban (apoyadas en los epígrafes y en las breves noticias que las acompañaban) un relato visual continuo que serpenteaba entre el material escriturario. Además, con el estallido de la Segunda Guerra, la sección cablegráfica fue creciendo en volumen, y también en imágenes, hasta alcanzar las ocho páginas en 1941.

9 No sabemos qué opinaba Arlt respecto a sus pinturas, pero sí que lo conocía ya que una de sus notas comienza a partir del siguiente cable: "Ámsterdam. Se rematará la valiosa colección de cuadros de Mannheimer que incluye obras de Rembrandt y Vermeer" (1940b).

10 El caso de las referencias a Nueva York en la prensa argentina es particular, porque tal como señala Gutman en su estudio sobre las imágenes urbanas de Buenos Aires que circularon en las revistas ilustradas entre 1900 y 1920: "cualquiera fuera el título bajo el cual aparecían las notas y dibujos de la ciudad vertical del porvenir, los lectores de las revistas ilustradas porteñas podían asociarlos fácilmente con Nueva York, sobre cuyos adelantos y construcciones se enteraban en las mismas revistas. En ellas se publicaban, con redundancia, notas e ilustraciones sobre las grandes construcciones 
contemporáneas neoyorquinas, envueltas en calificativos como 'grandiosas', 'colosales' o 'las más grandes del mundo' [...]. Las revistas mostraban también las nuevas, impactantes y modernas vistas aéreas de Nueva York que obtenían los aguerridos fotógrafos equilibristas, subidos a los altísimos andamios de los rascacielos en construcción” (2011, p. 33-34). Pero además, en el caso de Arlt, seguramente influyesen en esas representaciones las imágenes del cine. 